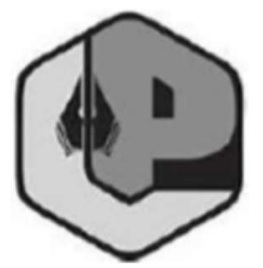

LINGUA PEDAGOGIA

(Journal of English Teaching Studies)

Vol.2, No.1, March 2020

Online: https://journal.uny.ac.id/index.php/lingua-pedagogia/index

\title{
Developing Graded Reading Materials to Enhance Extensive Reading Habit for Students of Senior High School
}

\author{
Authors: Muhammad Fauzi Al-Baihaqi \\ Yogyakarta State University \\ muhammad_fauzi2015@student.uny.ac.id
}

\author{
Siti Mukminatun \\ Yogyakarta State University \\ siti.mukminatun@uny.ac.id
}

\section{Abstract}

Improving literacy and a reading habit remains a major challenge to the Indonesian education system. To achieve maximum fluency in reading, the students should not only rely on classroom activities. They need a considerable amount of exposure or language inputs. Therefore, there is a need to develop self-access learning materials to enhance independent learning through extensive reading. The objectives of this research were to identify the students' target needs, identify the learning needs, and develop self-access graded reading materials to enhance extensive reading. The study employed the procedure of materials development by Jolly and Bolitho (2011) with some adaptations. The adapted stages include needs analysis, syllabus planning, materials production, materials evaluation, and revision for the final draft. The data of this research were collected from high school students in SMA N 8 Yogyakarta by using questionnaires and interview with the English teacher. The developed materials employ three levels of difficulty based on the number of headwords and readability ease. The materials were evaluated in terms of content, language, presentation, and layout appropriateness. The results of the materials evaluation showed a good outcome according to the expert judgment results.

Keywords: extensive, graded, reading, materials

\section{Introduction}

The literacy rate referring to reading habits in Indonesia is extremely low. The gap between the west and the east of Indonesia is quite noticeable. At its basic level, reading and writing skills are the underpinnings of literacy and cognitive development (Morais, 2017). Thus, under the language learning situation, building a strong foundation in reading is necessary prior to productive skills. Through reading, readers are exposed to plenty of language properties such as vocabulary, phrases, grammar, and syntax. The attempt to increase the literacy rate in Indonesia has been initiated in the past few years. Gerakan Literasi Sekolah/GLS (Movement of School Literacy) is a government-run program that encourages entire school elements, other government institutions, academics, publishers, mass media, and local communities to establish a long-life learning environment through the habit of reading. 
Due to this concern, reading must be actively fostered through classroom activities and independent learning. To achieve a sustainable habit in reading, the students must not only depend on classroom lessons as they need plenty of reading resources on their own. Essentially, extensive reading is all about choice. Learners are given freedom to pick the preferable genre, topic, modality, etc. Yet, the next problem is that how available the sources are. It is necessary that the school provides good books which also nurture their interest and support the learning of L2. To know how the reality is, the researcher conducted a preliminary observation questing the availability of English books in the sample school's library.

Based on the preliminary observation conducted in State Senior High School of 8 Yogyakarta, there are a number of English books available at the library. It was found that most of them are classics, romance fiction such as the Shakespeare's. Not only is the language rather challenging, but they are also not suitable for beginner readers. Therefore, there is a need to develop selfaccess learning materials to enhance extensive reading habit.

It should be considered that reading habits can reconstruct a well-established generation of Indonesia. Hence, investigation of problems regarding the practice of reading that occurs in the field is a prerequisite. Problems in the practice of English language teaching tend to be exclusive and are very contextual. It is due to the diversity of learning situations, different teaching experiences, different characteristics of students, facilities, etc. However, there must be common issues shared in most classroom settings. The learning outcome of a language class is of course language fluency.

To achieve such a stage of proficiency, first EFL students need a sufficient amount of exposure to language input. Renandya \& Jacobs (2016, p. 97) assure that when the students receive adequate L2 input, their word recognition skills increase, their vocabularies are enriched, their processing of spoken and written discourse improves, and eventually they get better proficiency. Thus, the question is how frequently the students in Indonesia are exposed to the target language. It becomes the first problem that in Curriculum 2013, English as a compulsory subject is given time allocation for only two lesson hours each week. The amount of exposure is severely limited and insufficient when they only count on classroom meetings. As a result, many Indonesian students are lack of vocabulary, grammar knowledge, and confidence in speaking or writing. Therefore, several scholars (Chang \& Millett, 2014; Day \& Bamford, 2002; Renandya \& Jacobs, 2016) highly recommend extensive reading and listening to foster language exposure to the students.

Renandya (2007) argues that extensive reading is a way to improve language proficiency through an enjoyable time spent on reading self-picked books/texts/materials. The key term for it stands to the word 'enjoyment' that the reading is aimed for recreational purposes. A further understanding of extensive reading is thenceforth put forward by its principles. They consist of the nature of extensive reading, the situation, and methodology that is essential for its success.

Graded readers are mentioned as reading materials suitable to assist an extensive reading program. Graded readers, by definition from the extensive reading foundation, are books of various genres that are specially designed for language learners. 'Graded' here is in the sense that the vocabulary and language structure are made in certain difficulty to suit the students' language mastery. The grading can be done in various ways. According to Dawson (1998), 
vocabulary load is usually restricted. Learners can acquire guessing meaning skill, as long as the graded books have a low density of new words. In line with the first core principle of extensive reading, the idea of graded readers is to help learners read with relative ease. They definitely cannot enjoy the reading activity with the difficult books and such anxiety of not understanding it (Dawson, 1998). Therefore, graded readers are a good starting point. As used in Oxford Publishing, Cambridge, and Penguin Readers, the main indicator for the grade is also the number of headwords. Yet, there are specifically two other indicators or criteria to mark the difficulty level. They are related to vocabulary and structure. The difficulty of vocabulary is determined by how frequent lexicons are used. The more frequent the word is used, the higher level will it belong to.

In sum, reading materials as language input have long been deliberated as an important resource in English language teaching to provide information, vocabularies, sentence structures, and other aspects in literacy development. However, the complexity of reading processes, strategies, and micro-skills creates challenges for students in acquiring reading. Teachers, as the facilitator for learning, may also be challenged in determining the appropriate approach to maximally impose students' reading habits. Referring to Curriculum 2013, some suggested procedures specifically in teaching reading can be through text-based instruction or a genre-based approach. Text types remain the learning focus and are commonly practiced in an intensive reading approach. Yet, only implementing that approach is found inadequate since students must acquire fluency and accuracy. Extensive reading has been promoted to enhance students' performance. The research questions to this study are then formulated as:

1) What are the target needs for extensive reading skills for the students of senior high schools in Yogyakarta?

2) What are the learning needs for extensive reading skills for the students of senior high school in Yogyakarta?

3) What are the characteristics of graded reading materials which are suitable to enhance extensive reading for senior high school students?

\section{Research Method}

This study belongs to the research and development (R\&D) category in the educational context. Gall, Borg, and Gall (2003) argue that this type of research is aimed to develop and validate educational products. Such products in ELT include a learning model, materials, media, etc. This type of research is classified into a critical or mixed approach that involves a mixture of quantitative and qualitative paradigms. The two approaches are equally important to answer the research questions. The final result of this study is a series of graded reading materials. It is expected that the materials can be used to attract students' interest in reading and eventually enhance reading fluency.

\section{Setting and Subject of the Research}

SMA N 8 Yogyakarta was selected as the sample school and as the place of study. The school is located in Jl. Sidobali No. 1, Muja-muju, Umbulharjo, Yogyakarta. As the common 
state high school in Yogyakarta, there are two majors offered i.e. natural science and social science. The subjects in this research were grade ten students and the English teacher. Among the 250 student population, 105 were engaged to fill the questionnaires from both natural science class and social science class.

\section{The Procedure of the Research}

Among the many models in materials development, this research employed Jolly and Bolitho's (2011) model with several adaptations. The procedure shows the complete stages in either developing new materials or some adaptations. Yet, it is suggested for the materials developers to adjust the full steps by accommodating only several ones. They should notice the strip path which is drawn to guide the optional stage. Jolly and Bolitho (2011) also add a note that says "Materials may be produced and evaluated without students use, e.g. by a colleague or professional. Most publishers still work this way. This does not reduce the need for evaluation after use by specific groups of students". According to these statements, the steps conducted in this study became: 1) identification of needs, 2) needs exploration and planning, 3) production of materials, 4) evaluation of materials and 5) reproduction of materials.

\section{Data Collection Techniques and Instruments}

The data gathered in this study were in the form of both quantitative and qualitative data. The qualitative data were taken chiefly utilizing interviews whereas the main sources of quantitative numbers came from the questionnaires of needs analysis and expert judgment. Nevertheless, the expert judgment might also insert some notes which can be a qualitative one.

The interview was conducted through an in-depth interview done by face-to-face mode. It consists of open-ended questions to provide qualitative data. Interview guidelines served as the instrument so that the interview process and resulted data were well-structured. Besides, the equipment in conducting the interview includes a recorder and other supporting tools.

The interview was carried out with the English teacher of SMA N 8 Yogyakarta. Later on, the data were used to balance the data from students' questionnaires. It meant to ensure whether what students fill in the need analysis' questionnaire was true or valid.

This type of instrument was used in the process of analyzing students' needs and also materials evaluation. The two questionnaires were designed differently that they employ the different approaches in answering the items.

The questionnaire for students' needs used open-ended questions that involved more thoughts. The responses were open to a lot of possibilities and not necessarily a simple one-word answer. The questionnaire in materials evaluation used the measuring system of the Likert scale in which responses are: (1) strongly disagree, (2) disagree, (3) agree, and (4) strongly agree. 


\section{Data Analysis Techniques}

As previously explained, the major source of quantitative data came from the questionnaire. In the first questionnaire, the technique of analysis was by calculating the percentage of answer items. The result data were used to figure out the tendency in each question. On the other hand, the questionnaire number two utilizes a different technique of calculation. The tendency of evaluation aspect was revealed through a component of descriptive statistics that is the mean score. The qualitative data were obtained from the interview and perhaps some notes in the materials evaluation questionnaire. The data were then analyzed through systematic information which enables readers to make inferences.

\section{Findings and Discussions}

\section{The Target Needs}

In target needs investigation, the students were asked about the necessities regarding the micro-skills in reading that they thought to be very beneficial for their reading development. There was no significant range among the selected skills except for the micro-skill of predicting meaning with the context. Around $60 \%$ of the respondents admitted that they need to read without looking up much on the dictionary. Therefore, the students needed to learn how to predict meaning with the help of synonym, collocation, illustration, etc. However, the other five choices were still important and they must be taken into account.

The identification of the students' lack was done by measuring the frequency or the amount of time that the students spare for reading and asking the difficulties that they find in reading English texts. The reading frequency of the students revealed in the following pie chart (Figure 1).

Based on the statements from Day and Bamford (2002) as well as Renandya and Jacobs (2016), extensive reading is aimed to promote reading habits. At any rate, the students are expected to read every day and finish one graded reader for each week. The result was nevertheless inconclusive. It cannot be inferred whether the students are lack of reading habit or not. Only a small portion of the chart tells that they read every day and has developed a prolonged reading habit. The pie chart at least shows that more than half of the students read occasionally within one to five hours. Only one-third of the respondents admitted that they read less than an hour a week. Presumably, they only do the reading in the classroom. 
Lingua Pedagogia

Vol.2, No. 1, March 2020

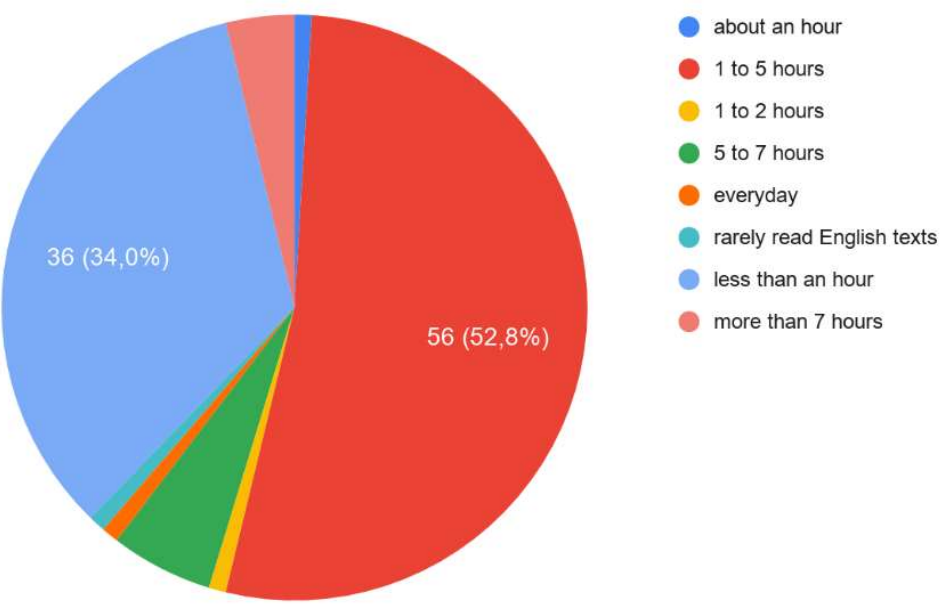

Figure 1. Students' Reading Habit

The next aspect of lack in reading is the gap between the learners' current reading proficiency and the target level. The next inquiry in the students' questionnaire was to know what has been the difficulty in reading English texts. The result was predictable that unfamiliar vocabularies remained a major difficulty in a lot of ELT settings. In this case, the results revealed that nearly three-quarters of the students feel challenged with unfamiliar words. Besides vocabulary, the other problems turned out to be quite relevant to the students as well. Some still find it difficult to understand more complex sentences and to look for reading materials that interest them. Moreover, some other students do not have much time to read instead. According to the teacher, the students are often pre-occupied with numerous tasks from the other subjects. Their time management has been the issue among the students so the English teacher decides to give classroom assignments only.

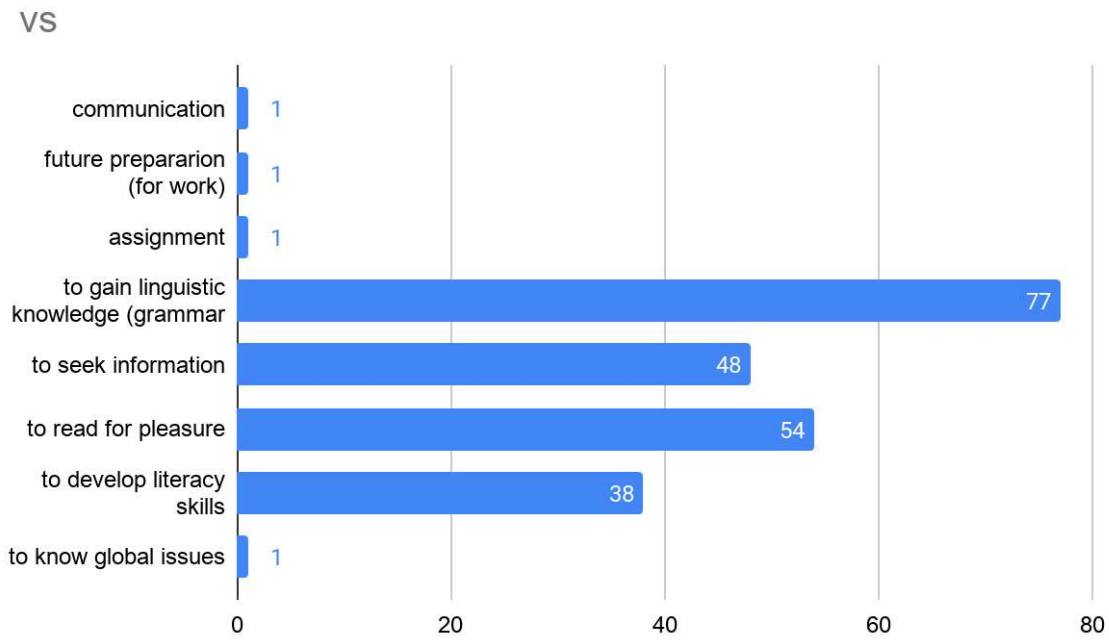

Figure 2. Students' Objectives

Furthermore, the teacher justified more explanation considering the lack of students' reading development. During the interview, the teacher explained that the 2013 curriculum imposes a 
lot of grammar lessons for elective English. The reading portion in the curriculum is adequate but to achieve reading fluency, the students desperately need self-access supplementary materials. Yet, the availability of English resources in the library was not adequate. The English novels only avail of the classic collections which do not attract the students at all. The library also subscribes daily Jakarta Post but the teacher also said that not many students pick up those kinds of reading materials.

The sub-components of 'wants' incorporate students' goals or objectives in reading English materials and their interests of a certain theme. Identifying the students' goals is essential to know what they expect to achieve in the reading materials. Then, the reading materials that would be developed must make adjustments to fulfill their wants. The students' interests are also prominent as the core principle of extensive reading is based on what the students like (Day \& Bamford, 2002; Macalister, 2015; Renandya \& Jacobs, 2016).

The trend in learning goals fell to gaining linguistic knowledge such as grammar and vocabulary. This fact correlates with the previous aspect of the needs analysis in which the students deal with unfamiliar vocabularies during reading. It is now clear that the students wanted to improve their vocabulary size. The other significant objectives that the students chose were respectively to read for pleasure, to seek stated information, and to develop literacy skills. There were around $50 \%$ of students who admitted reading as a leisure activity. The statistic is considered high for the fact that arousing students' interest in reading is relatively difficult in Indonesia (Pangestika, 2018; Ramadhani \& Herdiana, 2019). In this case, the teacher confirmed in the interview that the students must have read the materials that are close to them.

Moving to the students' interest, there were four highlights drawn from the result. They were respectively international culture, food, history and biography, and nature. Those four themes became the key references in deciding the topics of the books. In the realization, each theme was not made into one separated title. One book might contain subthemes and topics that are still interrelated.

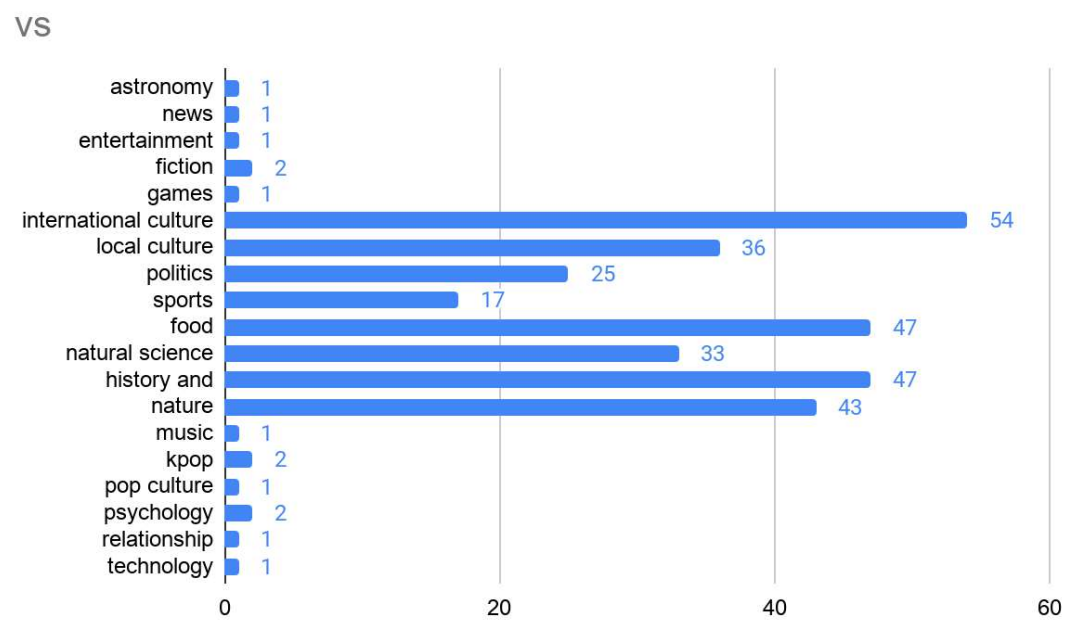

Figure 3. Students' Interests in Various Topics 
Lingua Pedagogia

Vol.2, No. 1, March 2020

\section{The Learning Needs}

To identify the suitable criteria for language input, the questionnaire specifically investigated the level of reading that the students were comfortable at. During the data collection, the students were told what headwords mean.

The result was that almost all students were assured of their level of difficulty based on the number of headwords. The data distribution between level 1 (250-400) and level 2 (400-700) is quite even. Together both levels comprise $83 \%$ of the total students. Presumably from the result, the students' level ranges from A1 to B1 (Aulia, Amalia, \& Rayi, 2019).

As Cooker in Tomlison (2008) and Hill (2013) say, good graded readers embody self-access learning. So, many international publishers such as Oxford Bookworm and Cambridge Discovery complement the graded readers with some activities. Two questions were proposed for this aspect. They relate to pre-reading activities and post-reading activities. This learning sequence is adapted from the intensive reading program. The while reading activity was excluded from the learning needs investigation because the outline and planning for whilereading activities was considered flexible, depending on the book contents. The activities for while-reading were pre-determined, applying all suggested activities to check understanding by Grabe and Stoller (2013, p. 166).

The role of pre-reading activities is to provoke students' background knowledge, stimulate schemata, and to help grasp the context. The availability of pre-reading activities fosters topdown processing in reading. So, students can easily predict and expect what to read (Smith, 2008). The options for this question are based on Richards (2015).

Essentially, each option had a similar purpose but the most preferable activity by the students was viewing pictures. The responses for the other options were positive as well. Therefore, some combinations were arranged to vary the list of activities.

The next property of the learning needs was the post-reading activity. The objective of embedding post-reading activities is to expand the acquired information through various critical activities. However, for this present study, the activities tend to exercise for linguistic reinforcement. The options took reference to Richards (2015) who argues that post-reading activity can just simply focus on the text, vocabulary, grammar, or discourse organization.

Parallel with the previous aspect in the need analysis, the students reaffirmed the fact that they wanted to expand their vocabulary size. However, there was a significant disparity in statistics with grammatical exercise with a gap of $34 \%$. 


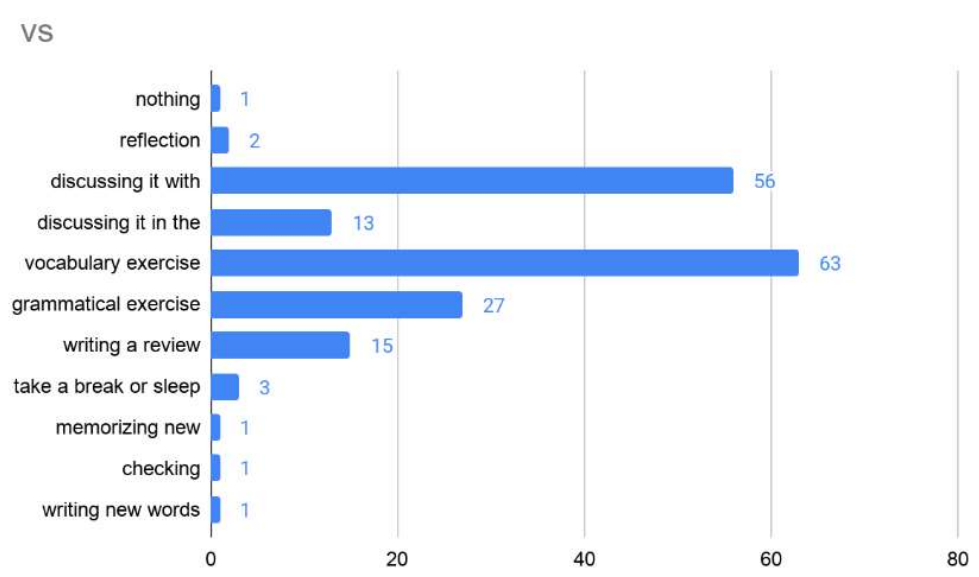

Figure 4. Preferable Post-Reading Activities

\section{The Outcome Product of Graded Reading Materials}

The main content of the reading materials is the text itself. The text for each level has a different trait. The text difficulty is mainly concerned with the number of headwords. They are respectively 400 headwords, 700 headwords, and 1000 headwords. The linguistic features in the reading materials are not strictly determined for specific vocabulary and sentence structures. Both linguistic aspects adjust to the content and information needed for the topic. However, there is still a type of grammar or vocabulary that is dominant in the text.

For descriptive and report text, the dominant linguistic aspects are present tenses, noun clauses, and descriptive language using adjectives. For biography and historical recount text, the highlights are past tenses and time signals. The design of activities in each unit is based on the need analysis. Yet, the format/sequence refers to Claridge (2012) and Hill (2013). Activities are divided into three types: pre-reading activity, while-reading activity, and post-reading activity.

The next stage in the production of the materials is to prepare the components of book design. Overall, the design of each book is divided into introduction, main reading materials, activities, glossary, and answer key. The introduction section of the book contains the title page, how to use, and the list of content. This part gives an overview of what the students are going to find in the book. On the title page, readers can see how many headwords that the book is written. Following that is a description of how to use the book. The page does not tell formally about the method or procedure to use the book; yet, it functions as the foreword to welcome the readers. Then, the list of content is necessary to reveal a brief outline of the book and to navigate the sub-topics with its page number. The main reading materials are the emphasis on the product. The focus is to convey factual information and to find joy when reading it. In this way, the students get enough exposure to language without pondering much about its forms. Consequently, linguistic features are not learned but acquired. 
The book is equipped with language learning activities to support classroom integration. As previously explained, each type of activity has a different utility. Before-reading activity is aimed to activate schemata or background knowledge. While-reading activity is to check readers' understanding, whereas after-reading activity is used to expand the obtained information. Activities provided in the book are however optional. The students may or may not do the activities. The reason goes back to one of the principles of extensive in which the focus is to gain personal experience, not necessarily a complete understanding (Day \& Bamford, 2002).

The next supporting aspect of language learning is the availability of glossary (Nation \& Chung in Long and Dought, 2009). The glossary serves as a mini-dictionary for some unfamiliar words. Later, the words are determined based on the online tool of frequency word checker. The lexicons categorized outside of the corpus are considered low-frequency words. At last, the answer key is presented in the book to promote self-access learning (Cooker in Tomlison, 2008). The readers can assure whether they can answer the provided activities correctly. This facility gives them mobility and opportunity for independent learning.

After finalizing the first draft of the materials, the next research procedure is materials evaluation. As to evaluate the appropriateness, the process of expert judgment also justifies the validity and trustworthiness of the reading materials. A Likert-scale questionnaire was employed to find out the strengths and weaknesses of the first draft. The results are divided into four aspects: content appropriateness, language appropriateness, presentation appropriateness, and design appropriateness. The results are shown in Table 1.

\begin{tabular}{ccccc}
\hline & Level 1 & Level 2 & Level 3 & Overall \\
\hline $\begin{array}{c}\text { Content } \\
\text { Appropriateness }\end{array}$ & 3 & 3 & 3.67 & 3.23 \\
\hline $\begin{array}{c}\text { Language } \\
\text { Appropriateness }\end{array}$ & 3 & 3 & 3.4 & 3.13 \\
\hline $\begin{array}{c}\text { Presentation } \\
\text { Appropriateness }\end{array}$ & 2.75 & 3.5 & 3.5 & 3.25 \\
\hline $\begin{array}{c}\text { Design } \\
\text { Appropriateness }\end{array}$ & 2.67 & 3 & 3.33 & 3 \\
\hline Mean & 2.85 & 3.12 & 3.47 & 3.15 \\
\hline \multicolumn{4}{c}{ Table 1 Expert Judgement Results }
\end{tabular}

Based on the expert evaluation, the materials for Level 1 demand considerable revisions. There is not much grammatical inappropriateness found in the reading materials. In sum, the requisite actions for revisions are reducing the number of photos, their size, and also adding more exercises. In this part, it exhibits more detailed elements and small attributes to be adjusted.

The book Level 1 and Level 2 share the same major problem that is the illustration. However, in Level 2, the activities are considered more varied and adequate so it results in a good grade.

The third receive more positive feedback from the expert evaluation. The illustrations are regarded as not too much and adequate. Major revisions still lie onto the layout and design by 
resizing the pictures and moving the page number. The following is a table exposing specific details to be modified.

\section{Discussions}

This research is categorized as an R\&D research in which the outcome of a series of self-access graded reading materials for students of senior high schools in Yogyakarta. The reading materials are designed with three separate levels for different proficiency in reading. In the development process, the researcher sticks to the research objectives which are to analyze students' target needs and learning needs and to develop the appropriate reading materials for students of senior high schools in Yogyakarta. From the thesis title, it seems that the scope of research is not narrowed down into specific settings and contextualized subjects. It is known that this research only involves school as a sample. However, all senior high schools in Yogyakarta generally share the same curriculum to which the aims of this materials development refer. The difference in students' characteristics is insignificant so there is not any drastic gap among the schools. Besides, the final product is a general reading book, not an ESP (English for Specific Purposes) materials.

This research successfully created a series of graded reading materials. All are created with the same unit design but the results from the expert judge remain different. Some criteria of good reading materials have become the excellence point but some others need to be improved, modified, and revised.

Calculating the Mean (X) from each component, the content appropriateness was averagely scored 3.23 which is classified into 'good' category. Concerning Curriculum 2013, the materials sufficiently meet the first criterion by BSNP (2011) in which the materials should be in line with the standard competency. The suitability of the curriculum is also equal at each level. Next, the linguistic aspect covering the vocabulary, sentence structure, cohesion, and coherence is assessed by 3.13. This mark is also considered favorable where the materials do not have excessive grammatical inappropriateness. Together with the cohesive devices in the texts, the language adequately makes a coherent story. Moreover, the grading level from the readability and word frequency is considered appropriate for each grade (Claridge, 2012; Hill, 2013). The third component is the appropriateness of the presentation. On average, the three books are scored 3.25. The result is less satisfactory for the first level of the book but is appropriate for the second and the third level. With this result, it is inferred that the activities are various and possibly make a good impact as self-access language learning especially in reading.

The first three components received generally positive feedback. In contrast, the design appropriateness turns out to have an unpleasant result. The total Mean (X) score for this aspect is 3. This is the lowest grade compared to the three other components. The weakness remains to illustrations which were overtly shown. Some were even useless and did not have the exact correlation to support general comprehension in reading.

As early mentioned, cutting the complete procedure in materials development can lead to several pitfalls. In this case, the application of materials is dropped due to effectiveness reasons. 
With the absence of that stage, there seems to be a missing link between the expert judgment results and the factual students' necessities. The analysis of the learning needs clearly shows that the students expect to see reading materials presented in colorful design and enclosed with various animations and photography. One criterion of good materials also argues that the illustrations should attract readers to read (Claridge, 2012). On the other hand, it is recognized that the major criticism for the three books falls into the number of illustrations that are overly presented. The result of this aspect needs further inquiry and direct validation from the students. The aim is to know whether the illustrations in the first draft of the materials are too dominant or not. Relating to the core of extensive reading (Day \& Bamford, 2002; Renandya \& Jacobs, 2016), the pleasure for which the students read the materials was unable to be identified as well. With all due respect, the attractiveness of materials, so far, is also based on the subjectivity of the expert judge. Thus, in the next project, it is suggested to conduct materials testing for the students for the betterment of this product quality.

In conclusion, the overall Mean (X) for the whole materials is 3.15. With this score, the first draft of the materials was considered appropriate with several notes. The weaknesses were immediately revised so the final draft of the materials can be observed in the appendix section.

\section{Conclusion}

Several key points need to be reiterated. Firstly, students often find unfamiliar words when reading English texts. The result correlates with the amount of time spent to read for a week. Half of the students roughly read from 1 to 5 hours per week. It can be inferred that the exposure and the amount of language input are inadequate. The statistic is not critical but it can be improved via reading a lot of English books. Secondly, the students want to improve their linguistic knowledge through reading so they need to learn several skills regarding linguistic knowledge such as predicting meaning using the context.

The second aspect that should be considered when developing materials is learning needs. Dissimilar with the previous needs, this research question refers directly to what the students need to have or to do during the learning activities. For language input, the reading materials need to be developed in different levels of difficulty. This is aimed to accommodate students with various levels of language proficiency. In terms of activities, they need to be varied and the most preferable ones are viewing pictures for pre-reading activities and linguistic exercise for post-reading activities. As for the layout and design, the majority agrees to have materials printed in color equipped with adequate illustrations. Based on the results of this study, suggestions were made for the following individuals.

To students of senior high schools in Yogyakarta, the produced reading materials are expected to meet the students' target needs so that they can be used to enhance reading for pleasure. The materials are self-access which enables them to be independent learners. The students are given the freedom to pick a suitable level of difficulty. Through this way, they can read with ease and understand the overall ideas of the story.

For English teachers, English teachers have a significant role in promoting self-access learning. In achieving reading fluency, the English teachers can encourage the students to read the 
Developing Graded Reading Materials to Enhance Extensive Reading Habit for Students of Senior High School

Muhammad Fauzi Al-Baihaqi, Siti Mukminatun

materials that they like. Rather, the teachers are suggested to use the graded reading materials in the classroom for the Sustained Silent Reading (SSR) Program.

Lastly, for future research, based on the critical discussion of this thesis, the researcher suggests that materials testing to the students is worth to be conducted. To publishers, they are recommended to publish more various titles so that the books can attract a large scope of students' interests.

\section{References}

Aulia, F., Amalia, T., \& Rayi, M. (2019). Solve Educational English Curriculum Alignment with the National Curriculum of Indonesia. Solve Education. https://solveeducation.org/

BSNP. (2011). Instrumen Penilaian Buku Teks Pelajaran Tahun 2011. https://bsnpindonesia.org/

Chang, A. C. S., \& Millett, S. (2014). The effect of extensive listening on developing L2 listening fluency: Some hard evidence. ELT Journal, 68(1), 31-40.

Claridge, G. (2012). Graded readers: How the publishers make the grade. Reading in a Foreign Language, 24(1), 106-119. DOI: 10.1177/2F0033688216631175

Cooker, L. (2008). Self-Access Materials. In B. Tomlinson (Ed.), English Language Learning Materials (p. 110-132). Continuum International Publishing Group.

Dawson, N. (1998). Penguin Readers Teacher' Guide to Using Graded Readers. Pearson Education.

Day, R., \& Bamford, J. (2002). Top Ten Principles for Teaching Extensive Reading. Reading in a Foreign Language, 14(2), 136-141.

Gall, M. D., Gall, J. P., \& Borg, W. R. (2003). Educational Research An Introduction (7th ed.). Pearson Education.

Grabe, W., \& Stoller, F. L. (2013). Teaching and Researching Reading (2nd ed.). Routledge.

Hill, D. R. (2013). Graded readers. ELT Journal, 67(1), 85-125. DOI: 10.1093/elt/ccs067

Jolly, D., \& Bolitho, R. (2011). A Framework for Materials Writing. In Materials Development in Language Teaching. Cambridge University Press.

Macalister, J. (2015). Guidelines or commandments? Reconsidering core principles in extensive reading. Reading in a Foreign Language, 27(1), 122-128. 
Morais, J. (2017). Literacy and democracy. Language, Cognition and Neuroscience, 33(3), 351-372. DOI: $10.1080 / 23273798.2017 .130511$

Nation, P., \& Chung, T. (2009). Teaching and Testing Vocabulary. In M. H. Long \& C. J. Dought, The Handbook of Language Teaching (p. 543-559). Blackwell Publishing.

Pangestika, A. M. B. (2018). A Small-scale Survey on Reading Motivation of Undergraduate Students. Islamic University of Indonesia.

Ramadhani, W. V. R., \& Herdiana. (2019). Reading Interest Problems in Indonesia (Book Day Opinion). ITS NEWS. https://www.its.ac.id/news/en/2019/05/22/reading-interestproblems-in-indonesia-book-day-opinion/

Renandya, W. A. (2007). The power of extensive reading. RELC Journal, 38(2), 133-149. DOI: $10.1177 / 0033688207079678$

Renandya, W. A., \& Jacobs, G. M. (2016). Extensive Reading and Listening in the L2 Classroom. In W. A. Renandya \& H. P. Widodo (Eds.), English Language Teaching Today Linking Theory and Practice (97-110). Springer International Publishing.

Richards, J. C. (2015). Key Issues in Language Teaching. Cambridge University Press.

Smith, F. (2008). Understanding Reading: A Psycholinguistic Analysis of Reading and Learning to Read (6th ed.). Lawrence Erbaum Associates.

\section{Author Profile}

Fauzi Baihaqi has been working as a part-time English tutor for four years. He teaches students of various ages from toddlers to middle schoolers. Fauzi recently graduated from the English department of Yogyakarta State University with a Bachelor's Degree in Education. Besides teaching, his interests include learning foreign languages and studying language literacy. He is especially keen on extensive reading so his future research is expected to discuss this topic further. 